\title{
Basic Passive Side-Day lighting Considerations for High Rise office Building
}

\author{
M. H. M. Zin, M. Jamil, N. L. N. Ibrahim, A. S. M. Tazilan
}

\begin{abstract}
High rise office building design is one of the essential buildings in construction industry due to the limited space especially in the urban area. After home, a high rise office building is an important space for human in modern era. Due to the issue of high energy consumption especially inefficient artificial light strategy, side-day lighting becomes the best solution for a high rise office building design. Despite providing efficient energy consumption, side-day lighting creates a positive impact to the worker as well as the office's indoor environment. Hence, this paper aims to explore the basic passive side-day lighting considerations that educate people especially for those who are involved in the building construction industry. Beside, this paper focuses on the passive design considerations due to the various advantages that not involved especially with complex electrical and mechanical system. A systematic literature review is the main methodology for this paper to identify the basic passive side-day lighting considerations for a high rise office building design. Base on this research, it revealed that eight elements for building design considerations should be applied to provide a better day lighting impact for a high rise office building design. Considerations for non-building design aspects should also need to be applied since those aspects contribute to produce a better day lighting impact for a high rise office building design.
\end{abstract}

Keywords : Passive side-day lighting, consideration, high rise office building.

\section{INTRODUCTION}

$\mathrm{D}_{\mathrm{ue}}$ to the current rapid development, high rise building design become the most effective building type in providing an efficient built up area within the limited site. Most of the urban city with limited site area applied this strategy to cope with the site surrounding as well as the high demand among users. It can be considered as an effective strategy especially to develop within a limited space area and being implemented

Revised Manuscript Received on May 15, 2020.

* Correspondence Author

M. H. M. Zin*, is with the Architecture Department, Faculty of Engineering and Built Environment, 43600 National University of Malaysia, Malaysia (phone: 012-9446404; e-mail: bay_sir_nar86@yahoo.com).

M. Jamil, is with the Architecture Department, Faculty of Engineering and Built Environment, 43600 National University of Malaysia, Malaysia (e-mail: maslinajamil@ukm.edu.my).

N. L. N. Ibrahim, is with the Architecture Department, Faculty of Engineering and Built Environment, 43600 National University of Malaysia, Malaysia (e-mail: nlni@yahoo.com).

A. S. M. Tazilan, is with the Faculty of Engineering and Built Environment, 43600 National University of Malaysia, Malaysia (e-mail: azimintazilan@ukm.edu.my).

(c) The Authors. Published by Blue Eyes Intelligence Engineering and Sciences Publication (BEIESP). This is an open access article under the CC BY-NC-ND license (http://creativecommons.org/licenses/by-nc-nd/4.0/) to the most of the cities in the world [35]. It consists of residential, office building and combination between both of the building design typology. Hence, high rise building is one of the complicated building design compare to the other buildings in term of design, building program, structures, materials, space layout, mechanical system, electrical system and other design requirements. Definitely, a high rise building give a big challenge for the local building professions especially architects, building engineers and energy planners to face various issues especially on buildings, energy and environment [38]. As we know, each of the building design contains its own character which responds to the site surrounding. In the other hand, every single building has its own program and spaces where good information especially on the site context should be considered. Definitely, to provide an effective high rise building design, deep understanding should be possess especially by the group of consultants who are responsible since at the early stage of design idea. It is a big challenge especially for the architect who lead the project which assisted by the other consultants in producing the building design to suit with the client's need. Climatic condition is another one of the vital factors that influence most on the high rise building design. By implement the site analysis, architects received actual information regarding on the site condition that will affect the building design.

Currently, office building become equally important as the residential buildings where people need a comfortable working space due to the challenging of working process. According to Kohn \& Katz [36], most of us think that home is the most important building while currently office building design is identify as one of the essential building design. Several of office building design emerged that in line with the current modern lifestyle as well as the working processes. Unfortunately, we need an efficient office building design due to the issue on the electrical lighting that increases the energy consumption [13]. Almost 35\% are consume for electrical lighting by the office building in Hong Kong [38] where it contributes as the most impact to the non-residential buildings [40]. Moreover, 30\% of the total energy consumption of the building contributes by electrical lighting in office buildings [66] as well as the major contributors to carbon dioxide $\left(\mathrm{CO}_{2}\right)$ emissions and global warming [3]. Human started to apply the artificial light as the main source since in 1930s due to the low electrical price and lighting equipment that affected the modern building design [48]. In addition, artificial lights become the major light source compare to the daylight that suit to the human's lighting demand for the office building after 1940's [16]. 


\section{Basic Passive Side-Day lighting Considerations for High Rise Office Building}

Beside, day light application to the building's space had reduced in 1970s due to te emergence of electrical light source [35]. Day light potentially produce a comfortable indoor environment to the all type of building design. Natural design strategy will create less energy consumption compare to the modern design method [8] such as solar shading devices, thermal mass cooling system, windows design or opening, insulation passive system,

solar gain and day light [63]. Based on a survey done by Galasiu \& Reinhart [21], open plan of office building design has the largest potential in terms of energy savings and technical ease for implementation compare to the other office building typology. Designers should consider the effective office building plan system especially on the flexibility for the occupants to manage their office space. Besides, it is essential to produce a quality office building design which can reduce the energy consumption as well as to achieve the efficient office building design.

Various impacts are produced by the office building design as the major contribution to the high amount of energy consumption [25]. Issue on the high energy consumption should be as the main factor for designers to produce an efficient office building design. According to Ubbelohde [63], day light should act as the major design strategy as an efficient method to solve the electrical energy consumption. Beside, day light as the primary energy source play a vital role that compliment the current and future needs for building design, human and environment [27]. It shows that, day light contributes to produce green building developments, enhance the energy consumption and visual comfort [41]. Demand on the efficient daylight design strategy is increasing to produce a quality of energy usage for a building design [35]. Daylight and natural ventilation are two natural sources that should be implemented in the building design hence reduce the energy load [29]. Definately, it is not an easy task to achieve the quality of daylight that can maximize the human comfortable level and reduce the energy consumption [23] since it required with a deep understanding to produce a proper daylight system. Desigeners need to accept this challenge since a proper daylight system would be the best strategy to reduce energy consumption which can be function as a main or back up energy system in a building design. A study done by Shahriar [60], shown that buildings in Malaysia should take the advantages of daylight in the Tropical climate that can increase the energy saving. While $\mathrm{Li}$ et al. [41], discovered that efficient lighting strategy that integrated with daylight are potentially reduce the electrical lighting usage and demand. Day lighting design strategy also influenced the energy performance inside a building as well as gives a positive impact to the global energy performance [12] .

Most of us know that, effective day light strategy will produced less amount of electrical lighting usage hence create a quality of building energy performance [35]. Previous study had revealed that, an integration design strategy between daylight and electrical light is the efficient way to create a better energy performance for an office building design [13].

Usually, two type of daylight strategies applied to most of the building design including office building which are side and top daylight strategy. Both of the daylight strategy should consider various factors that influence the effectiveness of daylight performance such as building form, level, site obstruction, material's type, climate and etc. Side day lighting is the common strategy for high rise office building especially for level which located at the middle of the high rise building. Study revealed that side day lighting design strategy function as the main method to produce daylight for a building design [37]. To achieve a quality of daylight system, people in the construction industry especially the consultant group and clients play a vital role as well as they should be educated in term of the daylight characteristics. Various type of ways have been implemented to determine the day lighting performance and suit to the high rise office building design. Currently, computer simulation is one of the efficient methods that can be applied for those who are involved in building construction. Computer simulation method assist designers to explore the potential of their building design to introduce the quality of day light inside the building spaces. It also inspired designers to create more experimental idea during the design process between the building design and day light's effects since various factors need to be considered. Moreover, designers should implement computer simulation as the main tools to produce a better daylight performance for their building design. It was revealed by a survey where $79 \%$ participants agreed to use computer simulation [57] that helps them to produce a quality of building design.

\section{RESEARCH MEHODOLOGY}

This research used literature review as the main source on the previous and current research such as journal, conferences, books, magazines, articles, presentation and working papers as the main references that focus on the side day lighting for high rise office building. All of the information was analyzed, compared and tabulated to produce the basic building considerations for day light. Moreover, the list of building considerations are based on the most significant element that being highlighted by most of researchers to produce quality of side day lighting for a high rise building

\section{GENERAL CRITERIA}

Basically, this paper discusses the two types of basic passive side-day lighting considerations that influence the day light performance in an office space for a high rise office building design. The two types are non-building design considerations and building design considerations as indicated in figure 1.

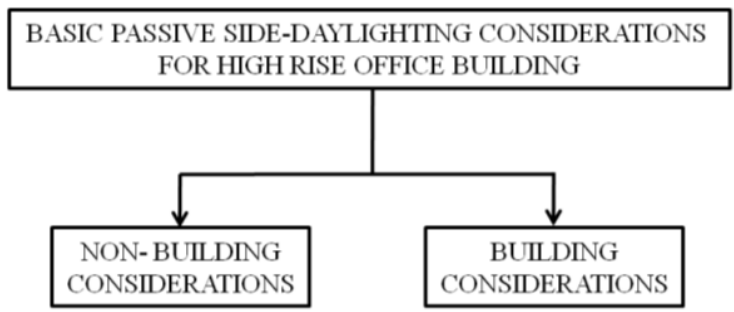

\section{Figure 1: Basic passive side-day lighting considerations for a high rise office building.}

Before discussing on the basic passive design considerations, there is another essential point that needs to be considered.

Published By:

Blue Eyes Intelligence Engineering

\& Sciences Publication

(C) Copyright: All rights reserved. 
Non-building basic criteria such as climate, weather and sky condition are initial factor that should be considered by designers. In other hand, designers need to educate themselves with accurate natural data especially on day lighting performance that will affect the building basic considerations to produce a quality day lighting performance.

Several factors influence the day lighting performance inside a building according to the various researches. Window's characteristics, shading device's design, building's obstructions, building's site, building forms and lighting strategies are some of the factors that influence the day light performance for a building design [49]. Other research also revealed that day lighting effect for a high rise building design is depends on window's size, type of glass, outdoor reflections surface, sun orientation and the environment characteristics [61]. Deep understanding among designers will produce a quality of day light performance in a room space for a building design especially when they consider some of the factors such as surrounding obstructions, windows design and sky characteristics [22]. This study will be more focus on the building design considerations since these factors are the major influencer to produce a better day lighting performance. Basically, this study will focus more on certain specific common or building basic criteria or building design considerations which related on the side-day lighting passive design strategy. The list of building considerations are building orientation, size and form, building core location, floor high and floor depth or lease span, position, orientation and size of window, glazing selection, ceiling design, space layout plan and shading strategies and light shelves and reflectance of interior spaces. The list of building considerations also based on research done by Ko et al. [35] which are building's lease span, program, floor to floor height, core's position and planning that should be considered in designing a tall building. A well-building design should not be focus on certain design considerations where integration between various factors will produce a quality of energy performance [20].

\section{BUILDING CONSIDERATIONS}

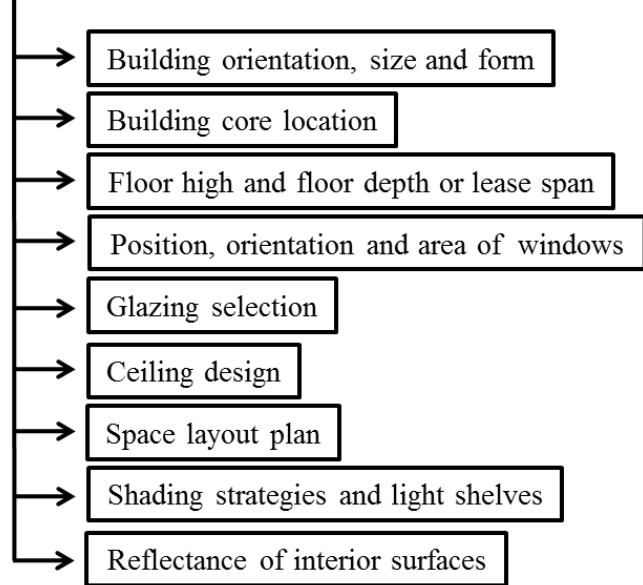

Figure 2: Building design considerations that influence day lighting performance.

To produce a high rise office building with a quality daylight system is not as easy task compare to the medium and low rise office building. According to Ubbelohde [63], it is a big challenge to introduce effective daylight design strategy especially to a high rise office building design that consists of several floor levels. A study revealed that two fundamental factors will influence the effectiveness in designing a high rise building which are the cost during the design process and the complexity of the environmental technology. Beside, high rise office building design possess a huge differences character compare to the medium even low rise office building design in term of building core, floor plate, floor to floor high, exterior wall system, mechanical systems, electrical systems, structural system and others. A quality of design understanding on the basic day lighting passive design strategy will assist the designers and clients to create an efficient of a high rise office building design.

\section{NON-BUILDING CONSIDERATIONS}

\section{A. Climate and weather}

Different geographic locations possessed a different climate and weather condition that affect the high rise office building design. Hence, different character of daylight will be produce due to those factors. High rise office building design that located in the cold climate area has a different design consideration compare to those buildings located in the tropical climate area. Buildings at the cold climate area need to consider the daylight performance especially during winter and summer season. Occupant need more daylight and heat especially during the winter season while they required quality daylight during summer. Compared to buildings located in tropical climate area, designers not only focus on the daylight effect on the building. Heat is another major factor that needs to be considered. The way on how the building responds to the daylight is totally different compare to the building in a cold climate area.

\section{B. Sky conditions}

Sky conditions are other non-building considerations that influenced the day lighting performance in a high rise office building design. Different geography location will produce different character of sky that also influenced by the climate condition. Hence, these factors create a different day lighting performance in an office space. According to Kroelinger [37] there are three types of sky conditions which are clear sky, overcast sky and partly cloudy sky. Research done by Mahdavi et al. [44] stated that, tropical climate area such as Malaysia received sunny and overcast sky for most of the year while a research done by Ahmed et al. [2] revealed that most of the time is predominantly by the intermediate sky compared to the overcast sky in Malaysia. These are the information that needs to be considered by architects to assure the distribution as well as the quality of daylight in the Tropical climate area [42]. A study done in Indonesia by Rahim \& Mulyadi [53] revealed that most of the sky conditions are dominated by intermediate sky (70\%), overcast sky $(15 \%)$ and clear sky (15\%). All of these researches educate architects to prepare themselves with reliable local data especially on daylight availability to enhance daylight quality in a high rise office building design.

\section{BUILDING CONSIDERATIONS}

\section{A. Building orientation, size and form}

Published By:

Blue Eyes Intelligence Engineering

\& Sciences Publication

(C) Copyright: All rights reserved. 


\section{Basic Passive Side-Day lighting Considerations for High Rise Office Building}

Building orientation and shape play a vital role to produce a quality of daylight in a high rise office building design. A research done in Tehran showed that the amount of glazing area plays a vital role to determine the building's orientation [18]. Effective building's orientation reflects the efficiency of energy performance where it contributes to design a high rise building design [33]. A maximum amount of day light give the impact to the energy saving that should be based on the relation of obstacles and orientation [22]. Less amount of glazing will oriented building to the south while more glazing will orient building to the southwest. A proper building's orientation potentially maximizes the day light performance inside a building space and minimizes the electrical or artificial light usage [44].

Most of the designer acts the building massing which represent shape and size of a building. Usually, architects will do their analysis and synthesis to create the best building orientation that relate with its form. As the major significant elements, building's form [24] influence also on the performance of the overall building design. Square and rectangular are the regular form for a high rise building design in order to achieve the effective cost for construction, structure, aesthetic value and efficient on the building area [1]. Mesiniaga Tower is one of the best bioclimatic high rise office building designs in Malaysia. It was designed by Kenneth Yeang which was recognized by Aga Khan Awards in 1995 and appeared with an effective orientation as well as building form. The orientation and form of the building respond to the site condition especially on the sun path system. According to Richards [56], all of the window areas facing the hot sides of the building have external louvers as solar-shading to reduce solar heat gain into the internal spaces. Those sides without direct solar insulation have unshielded curtain-walled glazing for good views and to maximize natural lighting. Rectangular shape is the common form that elongated from east to west in order to received good day lighting especially buildings that are located at the cold climate. Most of the high rise office buildings applied rectangular forms. Ling et al. [43] revealed that, a circle shape with ratio width/length $1: 1$ is the best shape to reduce the over sunlight that penetrate into a high rise building design compare to the other shape especially for building located in the Tropical climate area. The overall building form should be one of the major elements which impacts the building aesthetics and behaviour in developing a high rise building design [52].

\section{B. Building core location}

Position of the building core is another main factor that should be consider in producing a quality of daylight performance for a high rise office building. There are three types of core design which are single sided core, double core and central core [33] [36]. Most of the main structural elements are integrate into the core design such as elevators, stairwells [36], air conditioner system, water system, internet system and fire protection system as a strategy to maximize the usage of spaces as well as day light penetration. Building core also should be respond to the sun path, building orientation and form to encourage the daylight penetration as well as to maximize the rentable floor area. Beside, location and type of core is affected by several factors such as floor plate, space functions, mechanical and electrical system. According to Ling et al. [43], the external wall located on the east side received more sunlight penetration compare to the north, west and south area. This strategy also affected to the value of Overall Thermal Transmit Value (OTTV) where building core located on the east side will function as the thermal buffer and reduce the over sunlight penetration into the high rise office building design. Ken Yeang had study and applied the building core location which responds to the sun path as well as to reduce the OTTV value for Mesiniaga Tower. This study educates designers to understand the function of the building's core design and the climate characteristics.
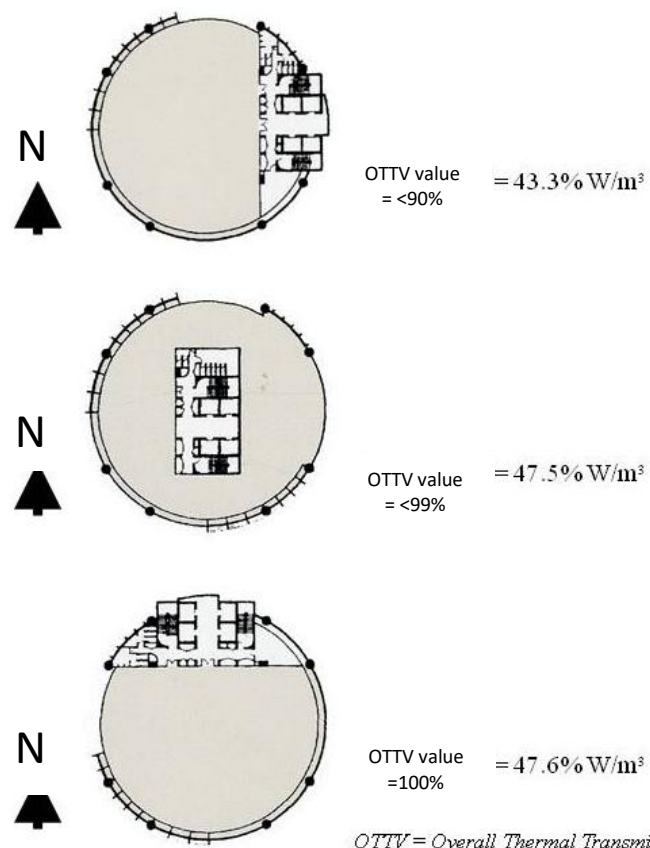

OTTV value $=47.6 \% \mathrm{~W} / \mathrm{m}^{3}$

OTTV = Overall Thermal Transmission Value

\section{Figure 3: Comparison between OTTV values according to the location of building core [56]}

\section{Floor high and floor depth or lease span}

Design requirement for high rise office buildings are different which mostly influenced by the location and climate factor. It is a big challenge to create a quality of day light penetration and perforation especially to the space located far from the high rise building's façade [23]. Normally the day light level decrease after penetrate through the windows to the deep distance inside a space area [14]. It is necessary to consider the floor to floor high for a high rise office building design as it contributes to achieve the quality of daylight. In Asia and United States, most of the high rise office buildings are designed with $4 \mathrm{~m}$ to $4.2 \mathrm{~m}$ for the floor to floor high [36]. Research made by Ling [43] indicated that the average floor to floor high is $4 \mathrm{~m}$ for a 30 stories building in Malaysia. It indicates that the floor to floor high for a high rise office building design is around $4 \mathrm{~m}$ to $4.2 \mathrm{~m}$ due to certain factor such as building structures, mechanical system, electrical system and building core without extremely considering the quality of day lighting. Research by Cammarano et al. [12] stated that daylight amount within a space is strongly influenced by two architectural features which are progressive increase in a room depth and a decrease

Published By:

Blue Eyes Intelligence Engineering

\& Sciences Publication

(C) Copyright: All rights reserved. 
in window-to-window ratio. Windows function as one of the vital elements where its high gives the impact on the day light zoning area [39] where architects need to provide an effective design to create a uniform daylight distribution [5]. Normally, architects applied the rule of thumb for day light where the depth of the floor spaces is twice to the ceiling high [24] while Micheal [46] stated that 27 feet was considered as the maximum depth for an office space. A study made by Carlisle [11] produced a simple formula which is the floor depth should be 1.5 to 2 times the maximum window high as shown in Figure 4.

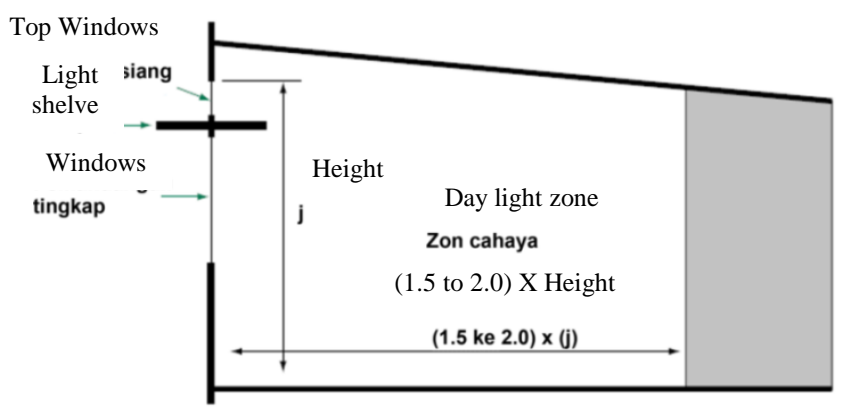

Figure 4: Daylight zone ratio between building high and depth [11].

This study is in line with research done by O'Connor et al. [50], Robertson [57] and Robinson \& Selkowitz [58] shown that 1.5 times the window head height is the practical depth of a day lighted zone while 2 times of the window height is more effective by applying a reflective light shelve. Hence, with standard window and ceiling heights between $2.7 \mathrm{~m}$ to $3 \mathrm{~m}$ will produce a plan's depth within $6.1 \mathrm{~m}$ from the window. Area that are located far from the windows will received low levels of daylight but it can be utilized as secondary spaces function especially for circulation and services area. Artificial lights would be the second choice for area which received low level of natural light and definitely it will affect the energy consumption as well as the occupant's activities. Window's arrangement is another factor that can contribute a uniform of daylight penetration. Strip windows can contribute more effective of daylight distribution compare to punched windows [58]. Other strategy that can improve daylight distribution by applying external light shelves which function as a shading and light reflection element. External light shelves can increase the total light because it can increase the proportion of light that comes from high angles in the sky [31].

\section{Position, orientation and area of windows}

Windows usually located at the building façade that function as the first design element to allow the day light penetration into a high rise office building design. It is in line with a study done by Roshan et al. [59] stated that windows provide the penetration of daylight is limited only to the certain area due to the deep of the space. Top day light and side day light systems are normally being applied to the building design. A high rise office building design normally utilized the side day light as the main source to received the natural light. Alrubaih et al. [3] agreed that side day lighting strategy is the common lighting method for a building design. The characteristics of the windows design should take into account such as windows arrangement, type of glasses, shading devices and other devices that potentially enhance the day light penetration [62]. Beside, windows glass area vitally assist the effectiveness of the day light performance [7]. The percentage of windows area should be within $30 \%$ to $60 \%$ of the building's envelope to achieve the quality of day light [9]. Architects also need to consider the effect of solar gain and heat when designing the windows [26]. The effectiveness of windows design will provide the occupant to received the quality of daylight. Moreover, occupants will provided with a view to the outside [51] that indicate the quality of the building and environment. Effective windows design especially on the position, orientation, shape and size should be considered in the early stage of design process. It is essential for designers where they need to create an efficient percentage of glaze area which can suit to the overall surface of high rise office building facade design.

The positioning of windows plays a major role in light distribution purposes. According to Bodart \& Herde [6], windows position function as the major influenced compare to the building's orientation for a building that equipped with a high percentage of glazing area. Windows should be located at the south and north of the building [47] that enhance the thermal insulation purposes [65]. Building located at the cold climate, the most efficient orientation is south-facing vertical glazing compare to north facing glazing while east and wet glazing orientation are not recommended due to the greatest solar gains in the summer time. Windows size function vitally to introduce day light. A study done by Bodart \& Herde [6] shown that, increasing the window area will produce more amount of daylight to penetrate inside an office building. Narrow and tall windows shape potentially creates a better daylight zoning area [48] especially to the space located far from the building façade. A tall window design will penetrate day light deeper to the space area [24]. Effective study on the site condition also should be implemented to enhance daylight penetration. One of the effective methods is implements the clerestory window type or high level windows to receive the deep day light penetration [5]. Large windows design should be balance to provide efficient day light performance and effective outside view [45]. Hence, we need to minimize the energy consumption which constrain the window's design and produce a small windows size. Architects can apply the window to wall ration (WWR) as the reference to provide a better day light performance. The best of WWR should be within from $30 \%$ to $80 \%$. Other study revealed that, to maximize day light and minimize energy performance should provide windows area within $20 \%$ to $30 \%$ form the wall area [4] [52]. The position of windows should be about $30 \mathrm{~cm}$ to $60 \mathrm{~cm}$ above the floor with $50 \%$ to $6 \%$ for the opening ratio [33]. A study done by Zain-Ahmed [67] revealed that wall to floor ratio is another factor which influenced the quality of daylight for office building in Malaysia. Remember that the effective delighted area extends into the building only about 2 times the width of a window and about 2 to 2.5 times its height [32]. Designers are preferred to calculate the size of suitable window area which base on the Figure 5 that need to multiply by 2.5 . 


\section{Basic Passive Side-Day lighting Considerations for High Rise Office Building}

$$
\begin{aligned}
& \text { Required Net } \\
& \text { Glazing Area }
\end{aligned}=\frac{2 \mathrm{X} \begin{array}{l}
\text { Average } \\
\text { Daylight } \\
\text { Factor }
\end{array} \mathrm{X}\left(\begin{array}{c}
\text { Area-Weighted } \\
\text { Average Reflectance of all } \\
\text { Interior Surfaces }
\end{array}\right)}{\text { Visible TransmittanceX } \begin{array}{l}
\text { Vertical Angle of Sky } \\
\text { Visible from Center of } \\
\text { Window }
\end{array}}
$$

Figure 5: Curved high ceiling located near to the window [58].

Most of the high rise offices buildings are designed with fully glaze windows that will produce another issue especially glare. The implementation of certain elements such as low-E coating glass, shading device and appropriate window position will create a quality day light distribution. Glazing is another essential criterion to produce a good quality of day light for an office building. Beside, other factors such as weather and obstacles are factors that should be considered to design effective glass windows.

\section{E. Glazing selection}

Despite window criteria, glazing selection will enhance more on day lighting distribution which collaborate with other design elements. Designers need to equip themselves with the glazing characteristics that suit to a high rise office building's space. Several of glazing can be applied to the windows that can produce a different daylight impact and it should be collaborate with the other passive side-day lighting design considerations. There are some basic considerations that should be highlight in selecting suitable glazing type such as color, visible transmittance, visible reflectance and spectral selectivity that contribute to produce quality of daylight. Visible transmittance is the most factor in determine the percentage of daylight that can penetrate to an office space through glazing. Designers need to consider in selecting a right choice in determining the ideal percentage of glazing's visible transmittance. Low transmittance value will produce a gloomy indoor ambience while high transmittance value provides more day light penetration in the office building area [58]. Some study shown that the effective transmittance value is in range of $50 \%$ to $70 \%$ to achieve the quality of daylight. Beside, visible reflectance should be considered where it also influences the effectiveness of day light performance. Visible transmittance and visible reflectance are related to each other. High value of visible reflectance will produce low value of visible transmittance and vice versa. It is proves that quality daylight is not achieve through the direct day light penetration while it also can be produced by effective daylight reflection. Other than that, the glass thickness also effects the day light penetration where it should be supported with the knowledge of the existing sky condition.

\section{F. Ceiling design}

Due to the deep of floor depth, it will discourage the penetration of sunlight as well as to produce quality daylight in an office area. Another strategy to solve this issue by providing an effective ceiling design located near to the windows area. A curved high ceiling design is a strategy to increase the daylight penetration far depth in an office area. Located near to the large double height windows, a curved high ceiling design will reflect the daylight more effective compare to the flat ceiling design. It should consider the floor to floor high and the equipment inside the ceiling such as air conditioning equipment and artificial lighting equipment that commonly equipped for a high rise office building design. According to Robinson \& Selkowitz [58], a sloped ceiling located near to the window area will enhance the daylight distribution inside a building's space. Beside, type of materials and light-colored for a ceiling plays a major role to create a good distribution of daylight. This strategy will enhance the day light distribution through the reflection between different materials inside an office building area.

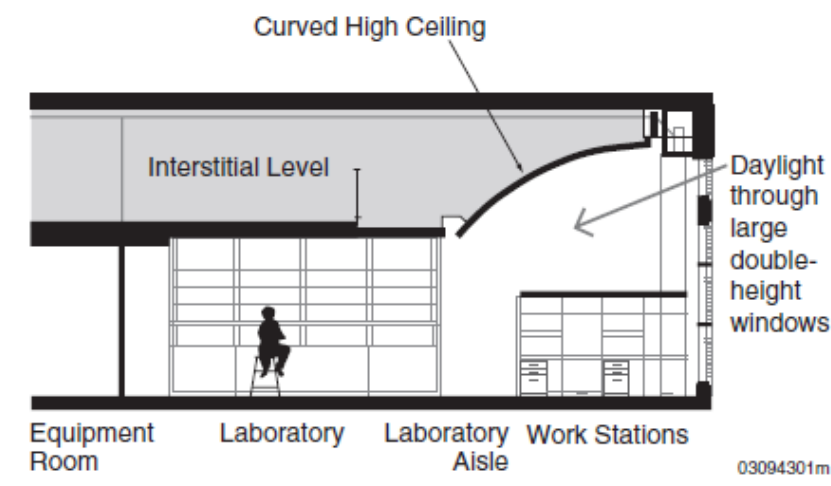

Figure 6: Curved high ceiling located near to the window [11].

G. Space layout plan.

A good space layout plan is another factor that will increase the quality of daylight performance inside a high rise office building design. Layout plan should be well designed as it functions as the major role that effect the building's energy performance [29]. Effective layout arrangement of space with less of wall and partition will make most of the space received a quality of daylight. Less of obstacles inside of an office building, daylight will penetrate more effective especially to the space located far from the window. Normally, most of the office space area difficult to receive the comfortable day light level. Based on a study in New York, almost $80 \%$ of the office area needs to be provided with electrical light while only $20 \%$ of the area receives the day light that called as day light zone area (DZA) [28]. Definitely, most of the office area needs to be provided with artificial light hence increasing the energy consumption for a high rise building. A shallow floor plate is one of the considerations that need to be applied for a high rise office building design that can allowed a quality of daylight penetration [48]. Some of the office building design receive the quality of day light by applying the cellular forms and narrow floor plan in 1950s. Unfortunately, most of the office building design implement the artificial light approach as the main light source.

According to Eisele \& Kloft [17] there are three type of office building layout plan which are closed plan, open plan and modified open plan. An office area can be designed as an open space without any fixed wall where it should be separated by not fully protected partition for daylight penetration purposes. Beside, major space especially working stations are designed as an open space area where there are no separator elements. Workers are freely to do their task anywhere or without any specific working station area. This strategy will create a quality of daylight penetration and increase the engagement among workers.

Published By:

Blue Eyes Intelligence Engineering \& Sciences Publication (C) Copyright: All rights reserved. 


\section{H. Shading strategies and light shelves.}

Glare and redirect light are another issues at the office working area due to the over daylight penetration especially to the space located near to the windows. Hence, this situation will create the uncomfortable working space area. To produce a quality of daylight, shading strategies is another alternative to reduce the amount of daylight. Excessive daylight penetration into the office building can be reduces by integrating window design with suitable shading elements to produce comfortable office space. [27]. Two strategies can be applied to reduce solar gain and glare inside an office building area which are exterior and interior shading strategies. It is essential to select the most efficient shading devices to produce quality day light for the high rise office building design [55]. Various types of materials and design of shading device can be applied to the facade of an office building. Architects are responsible to provide efficient shading devices [19] which can contribute well to the day light performance. Normally, two types of shading devices being applied to the building which are movable shading devices (venetian blinds, roller blinds and curtains) and static shading devices (light shelf and overhang) [55].

Various factors influence the efficiency of the exterior shading devices performance. Building orientation and latitude contribute to produce efficient static or flexible shading devices [10]. As the most common type of shading strategies, external shading device is the most efficient shading element to reduce solar gain and glare. Beside, suitable overhang and fin also potentially can be adapted to the building glazing area to produce efficient day light performance [15]. It should be balance between the purposes to reduce the daylight with the deep penetration of daylight. Light color will increase the function of shading devices compared to the dark color. Besides, the size and design of windows should be considered and it should be suit with the design of the shading device. However, deep shadings element for high rise building located in tropical climate is not reasonable since it will decrease daylight performance especially for the east and west directions [44]. This research also revealed that the depth of shading elements should not be over than $1.8 \mathrm{~m}$ for a high rise building design.

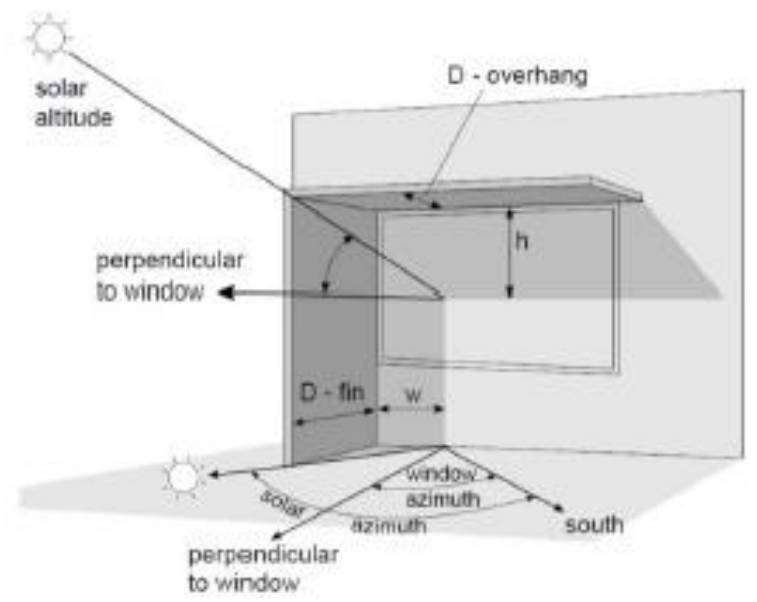

Figure 7: Strategy to determine shading device's design at the building's facade [58].

Light shelves or overhang is another effective strategy to increase the day light performance in an office space. Light

Retrieval Number: E9308069520/2020@BEIESP

DOI: 10.35940/ijeat.E9308.069520

Journal Website: www.ijsce.org shelves function as a multipurpose building's element where it potentially function as a day light reflectance element as well as harvest the day light penetration to the building space [57]. In other hand, light shelves diffuse or modify the daylight's intensity and increase the daylight's penetration to the office space as well as reduce the glare. Combination between a quality window designs with light shelf will produced a better daylight penetration by using a simple rule of thumb which is 2.5 times height of the top window and light shelves. Some of the researches revealed that exterior light shelves create a better daylight penetration compared to interior light shelves design. Figure 7 indicates the shading devices design strategy on the building's facade.

\section{Reflectance of interior surfaces.}

Good selection on ceiling, wall, floor and furnishing reflectance will produce a quality of daylight distribution in an office building design. As one of the essential elements, the interior surfaces and window's location are necessary to be identified at the early stage of design process [57]. Efficient day light performance can be achieve through the suitable selection of surface reflectance ceilings which integatre with the walls, floors and furnitures [57]. Certain factors should be considered especially type of materials, design, shape and location to produce a good reflection of daylight. Avoid using dark colors located near to the windows which will reduce the day light performance and create the glare issue. Light color would be the most efficient color as it functions to enhance the day light performance for the ambience of the office space.

\section{RESULTS AND DISCUSSIONS}

Generally, there are two types of basic passive side-day lighting considerations for a high rise office building design. Non-building considerations and building considerations are essential to produce an efficient day light performance. Both of these basic considerations potentially can assist designers and people who are involved in the building construction industry to produce an office building space with efficient day light performance. Beside, all of the elements for both basic considerations will function as a checklist for people in the building construction industry to have the initial basic information and as a reference for them to implement the best design strategy for the high rise office building design.

Table 1.0: Non-building considerations

\begin{tabular}{|c|l|l|}
\hline No & $\begin{array}{c}\text { Non-building } \\
\text { considerations }\end{array}$ & \multicolumn{1}{c|}{ Elements } \\
\hline \multirow{2}{*}{1} & \multirow{2}{*}{$\begin{array}{c}\text { Climate and } \\
\text { weather }\end{array}$} & $\begin{array}{l}\text { Different geography possessed different } \\
\text { climate condition. }\end{array}$ \\
\cline { 3 - 3 } & $\begin{array}{l}\text { Type of climate such as cold, tropical, dry, } \\
\text { temperate and polar }\end{array}$ \\
\cline { 3 - 3 } 2 & Sky condition & $\begin{array}{l}\text { Type of season such as winter and summer } \\
\text { sky conditions }\end{array}$ \\
\cline { 3 - 3 } & & $\begin{array}{l}\text { Type of sky conditions such as overcast and } \\
\text { intermediate sky. }\end{array}$ \\
\hline
\end{tabular}

Published By:

Blue Eyes Intelligence Engineering \& Sciences Publication (C) Copyright: All rights reserved.

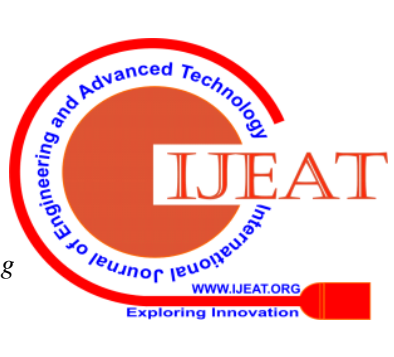




\section{Basic Passive Side-Day lighting Considerations for High Rise Office Building}

According to table 1.0, there are two aspects that should be considered by the non-building basic design considerations. It is essential to understand the climate and weather characteristics that affect the day light performance for a high rise office building design.

The uniqueness of different geography area is potentially can produces an efficient day light performance. Beside, day light performance in for the high rise office building design will be more efficient by considering the type of climates and seasons. The non-building basic considerations should be implemented at the early stage of the design process strategy to enhance the connection between sites surrounding and building design.

\begin{tabular}{|c|c|c|}
\hline No & $\begin{array}{c}\text { Building } \\
\text { considerations }\end{array}$ & Elements \\
\hline \multirow{5}{*}{1} & \multirow{5}{*}{$\begin{array}{l}\text { Building } \\
\text { orientation, size } \\
\text { and form }\end{array}$} & $\begin{array}{l}\text { Amount of glazing and obstacles influence } \\
\text { the building's orientation. }\end{array}$ \\
\hline & & $\begin{array}{l}\text { Less glazing area oriented to the south while } \\
\text { more glazing area oriented to the southwest. }\end{array}$ \\
\hline & & $\begin{array}{l}\text { Windows area facing the hot sides equipped } \\
\text { with external louvers while the other sides are } \\
\text { equipped with unshielded curtain-wall } \\
\text { glazing in the tropical climate region. }\end{array}$ \\
\hline & & $\begin{array}{l}\text { Rectangular shape that elongated from east to } \\
\text { west for building in the cold climate region. }\end{array}$ \\
\hline & & $\begin{array}{l}\text { Circle shape is the most effective building } \\
\text { shape in the tropical climate region. }\end{array}$ \\
\hline \multirow{3}{*}{2} & \multirow{3}{*}{$\begin{array}{l}\text { Building core } \\
\text { location }\end{array}$} & $\begin{array}{l}\text { Integrate the building service elements into } \\
\text { the core space. }\end{array}$ \\
\hline & & $\begin{array}{l}\text { Building core located at the east site of the } \\
\text { building as the thermal buffer. }\end{array}$ \\
\hline & & $\begin{array}{l}\text { Necessary to consider the most effective core } \\
\text { system such as sided core, double core and } \\
\text { central core. }\end{array}$ \\
\hline \multirow{4}{*}{3} & \multirow{4}{*}{$\begin{array}{l}\text { Floor high and } \\
\text { floor depth or } \\
\text { lease span }\end{array}$} & $\begin{array}{l}\text { Floor to floor high is between } 4 \mathrm{~m} \text { to } 4.2 \mathrm{~m} \text { for } \\
\text { building in Asia and United States. }\end{array}$ \\
\hline & & Floor depth is twice to the ceiling high. \\
\hline & & 27 feet is the maximum floor depth. \\
\hline & & $\begin{array}{l}\text { Floor depth is between } 1.5 \text { to } 2 \text { times the } \\
\text { maximum window's high. }\end{array}$ \\
\hline \multirow{10}{*}{4} & \multirow{10}{*}{$\begin{array}{l}\text { Position, } \\
\text { orientation and } \\
\text { area of windows }\end{array}$} & $\begin{array}{l}\text { Windows glass area is within } 30 \% \text { to } 60 \% \text { of } \\
\text { the building's envelope. }\end{array}$ \\
\hline & & Consider the effect of solar gain and heat. \\
\hline & & $\begin{array}{l}\text { Windows location at the south and north of } \\
\text { the building. }\end{array}$ \\
\hline & & $\begin{array}{l}\text { South-facing glazing is more efficient } \\
\text { compare to north-facing glazing. }\end{array}$ \\
\hline & & Narrow and tall windows are more efficient. \\
\hline & & $\begin{array}{l}\text { Implement the clerestory window design for a } \\
\text { deep day light penetration. }\end{array}$ \\
\hline & & Implement WWR within 30\% to $80 \%$. \\
\hline & & $\begin{array}{l}\text { Window's position is } 30 \mathrm{~cm} \text { to } 60 \mathrm{~cm} \text { above } \\
\text { the floor }\end{array}$ \\
\hline & & $\begin{array}{l}\text { Effective delighted area is } 2 \text { times the width } \\
\text { and } 2 \text { to } 2.5 \text { times the high of the window. }\end{array}$ \\
\hline & & Applied the low-E coating glass. \\
\hline \multirow{4}{*}{5} & \multirow{4}{*}{ Glazing selection } & $\begin{array}{l}\text { Consider the color, visible transmittance, } \\
\text { visible reflectance and spectral selectivity of } \\
\text { the glass. }\end{array}$ \\
\hline & & $\begin{array}{l}\text { Effective transmittance value is within } 50 \% \\
\text { to } 70 \% \text {. }\end{array}$ \\
\hline & & $\begin{array}{l}\text { High value of visible reflectance will produce } \\
\text { low value of visible transmittance. }\end{array}$ \\
\hline & & $\begin{array}{l}\text { Glass thickness influences the day light } \\
\text { penetration. }\end{array}$ \\
\hline \multirow[t]{2}{*}{6} & \multirow[t]{2}{*}{ Ceiling design } & $\begin{array}{l}\text { A curved high ceiling design is more effective } \\
\text { compare to flat ceiling design. }\end{array}$ \\
\hline & & Suitable material and color for ceiling. \\
\hline \multirow{2}{*}{7} & \multirow{2}{*}{ Space layout plan } & Less of obstacles such as walls and partitions. \\
\hline & & Shallow floor plate. \\
\hline
\end{tabular}

\begin{tabular}{|c|c|c|}
\hline & & Cellular form and narrow floor plan. \\
\hline & & $\begin{array}{l}\text { Select the best office building layout (closed } \\
\text { plan, open plan and modified open plan). }\end{array}$ \\
\hline \multirow{6}{*}{8} & \multirow{6}{*}{$\begin{array}{l}\text { Shading } \\
\text { strategies and } \\
\text { light shelves }\end{array}$} & $\begin{array}{l}\text { Select the most efficient shading devices } \\
\text { strategy (exterior and interior shading } \\
\text { devices). }\end{array}$ \\
\hline & & $\begin{array}{l}\text { Two type of shading devices which are } \\
\text { movable and static shading devices should be } \\
\text { considered to implement. }\end{array}$ \\
\hline & & External shading devices are more effective. \\
\hline & & $\begin{array}{l}\text { Light color increases the shading devices } \\
\text { performance. }\end{array}$ \\
\hline & & $\begin{array}{l}\text { The depth of shading devices should not be } \\
\text { over than } 1.8 \mathrm{~m} \text {. }\end{array}$ \\
\hline & & $\begin{array}{l}\text { Light shelves function as to reflect and } \\
\text { harvest the day light. }\end{array}$ \\
\hline \multirow[t]{2}{*}{9} & \multirow{2}{*}{$\begin{array}{l}\text { Reflectance of } \\
\text { interior surfaces }\end{array}$} & $\begin{array}{l}\text { Consider the type of materials, design, shape } \\
\text { and location. }\end{array}$ \\
\hline & & Implement light color material. \\
\hline
\end{tabular}

Table 2.0: Building considerations

Table 2.0 indicates the list of building considerations with specific elements that contribute to produce the day light quality. Nine of the basic building considerations possessed its own function and integrated to each other. A more detail analysis can be seen through the Figure 8.

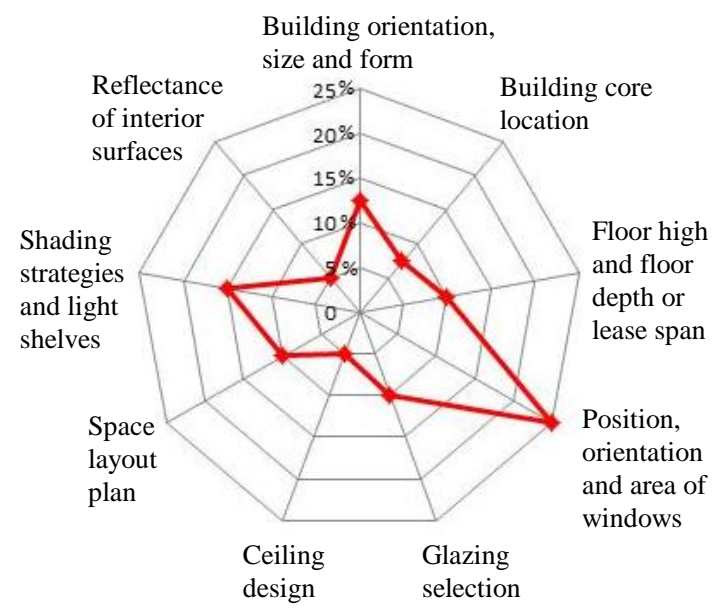

Figure 8: Percentage of elements for basic building considerations.

As indicates through Figure 8, position, orientation and area of windows function as the main elements for building considerations. Shading strategies and light shelves function as the second highest element. Building orientation, size and form function as the third element. Floor high and floor depth or lease span, glazing selection and space layout plan are the fourth elements that contribute for basic building considerations to produce a good quality of daylight. Building core location, ceiling height and reflectance of interior surfaces are the smallest percentage elements to introduce day light for a high rise office building design.

Published By:

Blue Eyes Intelligence Engineering

\& Sciences Publication

(C) Copyright: All rights reserved. 


\section{CONCLUSSION}

All of the design considerations are the most common elements that effect the daylight penetration to the high rise office building design. Each of the design considerations possesses its own characteristics that required designer to cope it to the other factors especially on the non-building design considerations.

This paper also educates designers to view nine of the building design considerations and assist them to understand the interaction between of those design considerations. Designers also should not focus totally on certain elements in building design considerations. Definitely, designers need to understand each of the characteristics among the elements and integrate them and suit with the non-building design considerations to produce a quality of day lighting strategy. Quality daylight performance for high rise office building design should be the main priority since it possessed a high potential to reduce the energy consumption especially for a high rise office building design.

\section{ACKNOWLEDGMENT}

The authors thank the Universiti Kebangsaan Malaysia (DIP-2016-006) and Ministry of Education (MyPhd and FRGS/1/2017/TK06/UKM/02/2) for proving their financial support which made this study possible.

\section{REFERENCES}

1. Ahmad, M. H., Ossen, D. R. \& Ling, C. S. No date. Impact of solar radiation on high-rise built form in Tropical Climate. University of Technology Malaysia, Malaysia.

2. Ahmed, A.Z., Sopian, K., Zainol Abidin, Z. \& Othman, M.Y.H. 2002. The availability of daylight from tropical skies - a case study of Malaysia. Renewable Energy 25(2002) : 21-30.

3. Alrubaih, M.S., Zain, M.F.M., Alghoul, M.A., Ibrahim, N.L.N., Shameri, M.A., \& Elayeb, O. 2013. Research and development on aspects of daylighting fundamentals. Renewable and Sustainable Energy Reviews 21(2013) : 494-505.

4. Arumi, F. 1977. Daylighting as a factor in optimizing the energy performance of buidings. Energy Build 1(1977) : 175-182.

5. Aziz, A. A. \& Adnan, Y. M. 2008. Incorporation of innovative passive architectural features in office building design towards achieving operational cost saving - the move to enhance sustainable development. In Proceedings from the Pacific Rim Real Estate Society (PRRES) Conference. Kuala Lumpur, Malaysia.

6. Bodart, M. \& Herde, A. D. 2002. Global energy savings in ofices buildings by the use of daylighting. Energy and Buildings 34(2002) : 421-429.;

7. Boychlaghem, N. 2000. Optimising the design of building envelopes for thermal performance. Automation in Construction 10(2000) : 101-112

8. Burton, S. 2001. Energy Efficient Refurbishment. James and James, London.

9. Bustamante, W., Vera, S., Prieto, A. \& Vasquez, C. 2014. Solar and lighting transmission through complex fenestration system of office buildings in a warm and dry climate of chile. Sustainability 6(5) : 2786-2801.

10. Carbonari, A, Rossi, G. and Romagnoni, P. 2002. Optimal orientation and automatic control of external shading devices in office buildings. Environmental Management and Health 13(4) : 392-404.

11. Carlisle, N. 2003. Laboratories for the 21st century: Best practices. Amerika Syarikat: National Renewable Energy Laboratory.

12. Cammarano, S., Pellegrino, A., Verso, V. R. M. L. and Aghemo, C. 2015. Daylighting design for energy saving in a building global energy simulation context. ScienceDirect 78(2015) : 364-369.

13. Chen, Y., Liu, J., Pei, J., Cao, X., Chen, Q. \& Jiang, Y. 2014. Experimental and simulation study on the performance of daylighting in an industrial building and its energy saving potential. Energy and Buildings 73: 184-191.
14. Chow, S.K.H., Li, D.H.W., Lee, E.W.M. \& Lam, J.C. 2013. Analysis and prediction of daylighting and energy performance in atrium spaces using daylight-linked lighting controls. Applies Energy 112(2013) : 1016-1024.

15. CHPS Best Practise Manual. 2002. Daylighting : Daylighting and fenestration design. United State : CHPS Inc.

16. Edwards, L. \& Torcellini, P. 2002. A literature review of the effects of natural light on building ocupants. United State : NationalRenewable Energy Laboratory.

17. Eisele, J. \& Kloft, E. 2003. High-rise manual typology and design, construction and technology. Basel: Birkhauser-Publishers for Architecture.

18. Fallahtafi, R. \& Mahdavinejad, M. 2015. Optimisation of building shape and orientation for better energy efficient architecture. Emeral Insight 9(4) : 593-618.

19. Freewan, A. A. Y. 2011. Improving thermal performance of offices in JUST using fixed shading devices. Low Energy Architecture 057(8) : 1860-1866.

20. Freewan, A. A. Y. 2014. Impact of external shading devices on thermal and daylighting performance of offices in hot climate regions. Solar Energy 102(2014) : 14-30.

21. Galasiu, A. D. \& Reinhart C. F. 2008. Current daylighting design practice : A survey. Building Research \& Information 36(2) : 159-174.

22. Haq, M.A.U., Hassan, M.Y., Abdullah, H., Abdul Rahman, H., Adullah, M.P.,Hussin, F. \& Said, D.M. 2014. A review on lighting control technologies in commercial buildings, their performance and effecting factors. Renewable and Sustainable Energy Reviews 33(2014) : 268-279.

23. Haqparast, F. \& Maleki, B. A. 2014. Daylighting and daylighting simulation. IJTPE 6(3) : 116-120.

24. Hawkes, D., McDonald, J. \& Steemers, K. 2002. The selective environment: An approach to environmentally responsive architecture. Canada: Spon Press.

25. Hens, H.C.L.C. 2009. Thermal comfort in office buildings: Two case studies commented. Building and Environement 44(2009 : 1399 1408.

26. Huat, N. B. \& Akasah, Z. A. 2011. An overveiw of Malaysia green technology corporation office building : A showcase energy-efficient building project in Malaysia. Journal of Sustainable Development 4(5) :212-228.

27. Holtz, M. J. \& Rogers, Z. 2012. Comparative evaluation of side-daylighting strategies. World Renewable Energy Forum / American Solar Energy Society Conference : 1-8.

28. Hinge, A., Frank, Y. \& Yancey, R. 2012. Retrofitting daylight controls in NYC office buildings : Let there be daylight. New York : Green Light New York, Inc.

29. Ibrahim, N. \& Ahmed, A. Z. 2006. Energy saving due to daylighting: A simplified prediction toll for wall envelope design of air-conditioned office buildings in Malaysia. Built Environmental Journal 3(1): 63-75.

30. John, W. 1997. Reinventing the workplace. United State: Architectural Press.

31. Johnsen, K. \& Watkins, R. 2010. Daylights in Buildings. United Kingdom : AECOM Ltd.

32. Karlen, M. \& Benya, J. 2004. Lighting design basics. Canada: John Wiley \& Sons, Inc.

33. Kannan, K. S. No date. Building envelope design considerations for energy-conserving high-rise buildings. United State : ASHRAE.

34. Khajehpour, S. 2001. Optimal conceptual design of high-rise office buildings. Tesis Dr. Fal, University of Waterloo.

35. Ko, D. G., Elnimeiri, M. \& Clark, R. J. 2008. Assessment and prediction of daylight performance in high rise office buildings. The Structural Design of Tall and Special Buildings 17(2008) : 953-976.

36. Kohn, A. E. \& Katz, P. 2002. Building type basics for office buildings. Kanada: John Wiley \& Sons.

37. Kroelinger, M. D. 2005. Daylight in buildings : Guidelines for deesign professionals. United States: The Mission on InformeDesign.

38. Lam, J. C., Li, D. H. W. \& Cheung, S. O. 2003. An analysis of electricity end-use in air conditioned office buildings in Hong Kong. Building and Environment 38(2003) : 493-498.

39. Lawrence Berkeley Technologies Program. 2013. Tips for daylighting with windows. Amerika Syarikat: United State Department of Energy.

40. Li, D. H. W., Lam, J. C. \& Wong, S. L. 2002. Daylighting and its implications to overall thermal transfer value (OTTV) determinations. Energy 27(2002) : 991-1008.

Published By:

Blue Eyes Intelligence Engineering

\& Sciences Publication

(C) Copyright: All rights reserved. 


\section{Basic Passive Side-Day lighting Considerations for High Rise Office Building}

41. Li, D. H. W. Cheung, A. C. K., Chow, S. K. H. \& Lee, E. W. M. 2013. Study of daylight data and lighting energy savings for atrium corridors with lighting dimming controls. Energy and Buildings 72(2014) : 457-464.

42. Lim, Y.W. \& Ahmad, M.H. 2013. Daylighting as a sustainable approach for high rise office in tropics. Internal Journal of Real Estate Studies. 8(1) : 30-42.

43. Ling, C. K., Hamdan, M. H. \& Ossen, D. R. 2007. The effect of geometric shape and building orientation on minimising solar insolation on high-rise buildings in hot humid climate. Journal of Construction in Developing Countries 12(1) : 27-38.

44. Mahdavi, A. H., Inangda, N. \& Rao, S. P. 2015. Impacts of orientation on daylighting in high-rise office buildings in Malaysia. Journal of Design and Built Environment 15(2) : 29-38.

45. Mangkuto, R.A., Rohmah, M. \& Asri A. D. 2016. Design optimisation for window size, orientation, and wall reflectance with regard to various daylight metrics and lighting energy demand: A case study of buildings in the tropics. Applied Energy 164(2016) : 211-219.

46. Micheal, R. 1955. Modern office building. London: Batsford Ltd.

47. Naamandadin, N. A., Sapian, A. R. \& Noor, N. A. M. 2016. Site planning and orientation for energy efficiency : A comparative analysis on three office buildings in Kuala Lumpur to determine a location for building shading device. Key Engineering Materials 700(2016) 247-255

48. Nik Ibrahim, N. L. 2002. Rules of thumb in daylighting design:University of Sydney, Australia.

49. Ochoa,C.E., Aries, M.B.C. \& Hensen, J.L.L. 2012. State of the art in lighting simulation for building science: A literature rieview. Journal of Building Performances Simulation 5(4) : 209-233.

50. O'Connor, J., Lee, E., Rubinstein, F. \& Selkowitz, S. 1997. Tips for daylighting with window : The integration approach. United States: Ernest Orlando Lawrence Berkeley National Laboratory.

51. Ozdemir, A. 2010. The effect of window view's openness and naturalness on the perception of rooms' spaciousness and brightness: A visual preference study. Scientific Research and Essay 5(16) : 2275-2287.

52. Park, S. M., Elnimeiri, M., Sharpe, D. C. \& Krawczyk, R. J. 2004. Tall building form generation by parametric design process. Proceedings of the CTBUH 200 Conference. Seoul, Korea. 1-7.

53. Rahim, R. \& Mulyadi, R. 2004. Preliminary study of horizontal illuminance in Indonesia. 5th SENVAR : 1-10.

54. Reinhart, C. F., Mardaljevic, J. \& Rogers, Z. 2006. Dynamic daylight performance Metrics for sustainable building design. The Journal of the Illuminating Engineering Society 3(1) : 7-31.

55. Reinhart, C. \& Fitz, A. 2006. Findings from a survey on the current use of daylight simulations in building design. Energy and Buildings 38(7) : 824-835.

56. Richards, I. 2001. T.R. Hamzah \& Yeang: Ecology of the sky. Australia: The Images Publishing Group Pty Ltd.

57. Robertson, K. No date. Daylighting guide for buildings. Canada : Home to Canadians.

58. Robinson, A. \& Selkowitz, S. No date. Tips for daylighting with windows. United State : U.S. Department of Energy.

59. Roshan, M., Kandar, M. Z., Mohammadi, M. P. \& Dodo, Y. A. 2013. Empirical validation on daylight simulation tool for a test office with anidolic daylighting system. Journal of Basic and Applied Scientific Research 3(9) : 104-112.

60. Shahriar, A. N. M. 2006. Daylight penetration in Malaysian high-rise office buildings. Tesis S. Sn, Alam Bina, Universiti Islam Antarabangsa Malaysia.

61. Srinivasan, B. \& Meenambal. 2016. Optimization of day lighting in high irse building through declination angle and reflecting device. IJAER 3(3) : 40-49.

62. Sun, C., Giles, H. \& Lian, Z. 2014. The dynamic impact of window characteristics on shading factor and energy consumption. Solar Energy 102(204) : 1-13.

63. Ubbelohde, M. S. 2002. Daylight design for multistory offices: Advanced window wall design in practise. Commercial Buildings: Technologies, Design, Performance Analysis, and Building Industry Trends 385-400.

64. Wilkinson, S. J. \& Reed, R. G. 2006. Office building characteristics and the links with carbon emissions. Emerald Insight 24(3) : 240-251.

65. Yeang, K. 1999. T.R. Hamzah \& Yeang: Selected Works (Master Architect Series, 3). Japan: Books Nippan.

66. Yoo, S., Kim, J., Jang, C.Y. \& Jeong, H. 2014. A sensor-less LED dimming system based on daylight harvesting with BIPV system. OPTICS EXPRESS 22(1) : 132-143.

Published By:

Blue Eyes Intelligence Engineering

\& Sciences Publication

(C) Copyright: All rights reserved.
67. Zain-Ahmed, A., Sopian, K., Othman, M.Y.H., Sayigh, A.A.M. \& Surendran, P.N. 2002. Daylighting as a passive solar design stategy in tropical buildings : a case study of Malaysia. Energy Conservation and Management 43(2002) : 1725-1736.

\section{AUTHORS PROFILE}

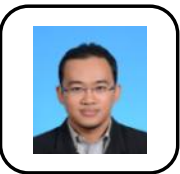

M. H. M. Zin is a $\mathrm{PhD}$ student at the Architecture Department of Faculty Engineering and Built Environment in Universiti Kebangsaan Malaysia (UKM) He graduated his Bachelor in Architecture in 2010 and Master Science in Architecture in 2013 from Universiti Kebangsaan Malaysia (UKM).

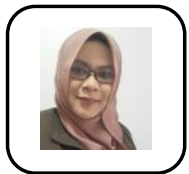

M. Jamil is an Associate Professor at the Architecture Department, Faculty Engineering and Built Environment in Universiti Kebangsaan Malaysia (UKM).

N. L. N. Ibrahim is an Associate Professor at the Architecture Department, Faculty Engineering and Built Environment in Universiti Kebangsaan Malaysia (UKM)

A. S. M. Tazilan is an Associate Professor at the Architecture Department, Faculty Engineering and Built Environment in Universiti Kebangsaan Malaysia (UKM). 